\title{
Dyskursy pracy i zabawy w wysokobudżetowym segmencie gier wideo: fokalizacja i logika operacyjna
}

Mateusz Felczak 


\section{Dyskursy pracy i zabawy w wysokobudżetowym segmencie gier wideo: fokalizacja i logika operacyjna}

Mateusz Felczak

TEKSTY DRUGIE 2017, NR 3, S. 210-224

DOI: $10.18318 /$ td.2017.3.12

\section{Wprowadzenie}

Celem tego artykułu jest analiza i interpretacja ewolucji dyskursów skupionych wokół kategorii pracy i zabawy $\mathrm{w}$ wysokobudżetowym segmencie gier wideo. W tym kontekście szczególnie interesuje mnie wpływ narzędzi cyfrowej dystrybucji gier na ich warstwę mechaniczną i wizualną. Dwa główne obszary, na których chciałbym się skoncentrować, będą obejmować analizę wybranych strategii fokalizacji i implementacji mechaniki interakcji, ilustrujących przesunięcie definicji komputerowej rozrywki, w której coraz mniejsze znaczenie ma aspekt bezcelowej i beztroskiej zabawy, rośnie zaś tendencja do projektowania (i opisywania) gier w kategoriach wysiłku, pracy i nagrody. Tak sformułowana teza wyjściowa wymaga użycia narzędzi, które pozwolą na połączenie dociekań narratologicznych z analizą krytyczną strategii projektowania i dystrybucji gier. Z tego powodu kolejno przedstawione zostaną tu zarówno koncepcje problematyzujące kluczową relację między pracą i zabawą, jak i wsparte logiką operacyjną - teorią z dziedziny studiów
Mateusz Felczak

- mgr, doktorant

WZiKS UJ, związany

z Instytutem Sztuk

Audiowizualnych

oraz Instytutem

Bliskiego i Dalekiego

Wschodu. Interesuje

się przemianami

modeli monetyzacji

i dystrybucji gier oraz

ich funkcjonowaniem

w obiegu fanowskim.

Redaktor działu gier

wideo w czasopiśmie

„EKRANy", współpra-

cownik magazynu

"Glissando". Publiko-

wał m.in. w „Kulturze

Popularnej,",Homo

Ludens,, ,Praktyce

Teoretycznej" oraz

„Kulturze Współ-

czesnej." Kontakt:

mateusz.felczak@

doctoral. 
nad oprogramowaniem - analizy wykorzystujące koncepcję fokalizacji w ujęciu Mieke Bal.

Prezentowane tu analizy, choć oparte na reprezentatywnych przykładach produkcji AAA, stanowią jedynie wycinek całego spektrum zjawisk dotyczących zarówno technologicznego, jak i odbiorczo-interakcyjnego wymiaru współczesnych growych tekstów kultury'. Wykorzystane w tytule pojęcie dyskursu dla tak sformułowanego zadania badawczego chciałbym zoperacjonalizować podwójnie: w rozumieniu empirycznym, jako „ramę poznawczą służącą do intencjonalnego kształtowania powszechnie podzielanych wyobrażeń i sensów"2 (analiza dyskursu badałaby więc jego perswazyjną skuteczność), oraz jako system znaczeń, który kryje w sobie pewne przesłanki natury ideologicznej (a zatem ciekawi mnie też kwestia, jakie interesy są wspierane przez rozmaite dyskursy).

\section{Praca i zabawa}

Ścisłe rozgraniczenie między pracą i zabawą nastręczało pewnych problemów już Johanowi Huizindze, który choć podtrzymywał definicyjny wymóg bezinteresownego charakteru tej ostatniej, musiał na kartach Homo ludens uciekać się do wybiegu jego uzasadnienia przez umieszczenie celów zabawy „poza granicami bezpośrednio materialnych interesów"3 ludzi. Z tego też powodu holenderski badacz w obręb zabawy chętniej był skłonny włączyć mit i rytuał niż np. współczesne mu formy „na wskroś świeckiego"4 sportu. Z perspektywy analizy komputerowych tytułów wysokobudżetowych kulturotwórczy wymiar zabawy, tak ważny dla pierwszych teoretyków ludologii, odsłania swój dodatkowy wymiar, manifestujący się w dynamicznym dialogu między graczami i twórcami gier. Jak płynny jest to podział, udowadniał już w 2005 roku Julian Kücklich ${ }^{5}$, postulując wprowadzenie terminu playbour („pracozabawa”)

1 Tekst ten jest powiązany $z$ artykułem dotyczącym dyskursów pracy i zabawy w grach sieciowych z perspektywy społeczno-ekonomicznej, opublikowanym w "Praktyce Teoretycznej” $2014 \mathrm{nr} 4$ (14).

D. Howarth Dyskurs, przeł. A. Gąsior-Niemiec, Oficyna Naukowa, Warszawa 2008, s. 15. . Huizinga Homo ludens. Zabawa jako źródło kultury, przeł. M. Kurecka, W. Wirpsza, Aletheia, Warszawa 2007, s. 23.

4 Tamże, s. 304.

5 J. Kücklich Precarious Playbour: Modders and the Digital Games Industry, "The Fiberculture Journal" issue 5 . 
na określenie nieodpłatnej, twórczej pracy autorów modyfikacji do gier, których owoce aktywności nie tylko pomagają zwiększyć popularność danego tytułu, ale też mają możliwości same stać się samodzielnym produktem. Od czasu ukazania się tej publikacji rozmaite podmioty działające na rynku gier komputerowych - a zwłaszcza jego związanej z komputerami osobistymi części, będącej w tym artykule szczególnym przedmiotem zainteresowania - podejmowały mniej lub bardziej udane próby skapitalizowania wytworów pracy fanów. Niektóre z nich zakończyły się spektakularnym fiaskiem, jak starania Gabe'a Newella, szefa platformy Steam, który przez krótki czas wprowadził w swoim cyfrowym sklepie możliwość zakupu (tradycyjnie darmowych) modyfikacji do niektórych popularnych tytułów, takich jak The Elder Scrolls: Skyrim. Co ciekawe, przeprowadzona w odpowiedzi na te działania specyficzna „akcja protestacyjna” fanów opierała się m.in. na projektowaniu modyfikacji, które wyposażały awatary postaci świata Skyrima w transparenty z hasłami wyszydzającymi chciwość potentata cyfrowej rozrywki.

Szybka ewolucja i ekspansja przemysłu gier wideo zaowocowały na gruncie groznawstwa rozwinięciem pomysłów Kücklicha. Większość z nich skupiała się na ekonomicznym wymiarze cyfrowej pracy i na konieczności dywersyfikacji pojęć z nią związanych, czego przykładem może być propozycja Arwida Lunda ${ }^{6}$, opierająca się na podziale samej czynności grania na aktywności przynoszące wymierne ilościowe i jakościowe efekty. Ten aspekt analizy dyskursów pracy i zabawy pozostaje dla mnie niezbędnym kontekstem prezentowanych tu analiz. W ich świetle zanika jednak niekiedy to, co stanowi kluczowy element interaktywności w grze: twórcze negocjowanie indywidualnych relacji między poszczególnymi aktorami budującymi growe doświadczenie.

\section{Fokalizacja i logika operacyjna}

W swojej pracy będę za Mieke Bal wykorzystywał szeroką definicję fokalizacji jako relacji między aktem widzenia i tym, co postrzegane. Takie ujęcie pozwoli mi nie tylko na prześledzenie warunkowanych mechaniką gry zależności między graczem, jego awatarem i światem przedstawionym, ale i na uwzględnienie towarzyszących temu kontekstów estetycznych oraz ideologicznych. Osią proponowanej przeze mnie analizy są z jednej strony pytanie

6 A. Lund Playing, Gaming, Working and Labouring: Framing the Concepts and Relations, "tripleC" 2014 No. 12 (2). 
o sprawczość i podmiotowość gracza wobec narzuconej narracyjnie struktury gry, z drugiej zaś kwestia konfliktu deiktycznego, jaki rozgrywa się w obrębie jej diegezy, angażującego zróżnicowane strategie percepcyjne, przestrzenne i relacyjne. Moim celem będzie zatem prześledzenie procesów, za pomocą których growy "teatr mediatyzacji”" stara się pozycjonować odbiorcę wobec pewnej koherentnej wizji świata w danym wycinku czasu, konstruując tym samym narracje dotyczące polityk pamięci oraz specyficznego realizmu, powiązanego z kategorią odbiorczej przyjemności. Przedmiotem mojej analizy będą głównie produkcje z gatunków cRPG oraz FPS powstałe w ostatnich dwóch dekadach, co oprócz analizy polityk pracy i przyjemności pozwoli zawrzeć również refleksję genologiczną dotyczącą procesów kształtowania kategorii odbiorczych w grach segmentu AAA.

Jako narzędzie analizy gier chciałbym zaadaptować zaproponowany przez Noaha Wardrip-Fruina (2012) podział artefaktów mediów elektronicznych, nazwany przez niego logiką operacyjną (Operational Logics). Postuluję potraktowanie go jako warstwowego modelu gry wideo. Uwzględnia on poziomy danych, procesów, interfejsu („powierzchni”), interakcji, autorów i odbiorców. Taka konceptualizacja pozwala na krytyczne przyjrzenie się procesom, na jakich opiera się komunikacja między poszczególnymi składowymi gier oraz w obrębie nadawczo-odbiorczego środowiska, w którym funkcjonują. Wykazanie przydatności zaadaptowania elementów dyskursu z dziedziny software studies do analizy wysokobudżetowych tytułów implementujących zaawansowane techniki fokalizacji wydaje mi się kluczowym krokiem nie tylko partykularnej interpretacji, ale też określenia funkcjonowania gry we współczesnym obiegu medialnym.

W modelu Wardrip-Fruina dane określają typ zmiennych, które są kluczowe dla mechaniki rozgrywki - ich identyfikacja umożliwia graczowi rozpoznanie warunków zwycięstwa i głębsze zrozumienie reguł gry. Dane nie muszą mieć bezpośredniego wpływu na fokalizację, ale poprzez określenie ram rywalizacji determinują następną warstwę - procesy - już ściśle określającą charakter interakcji i pozycjonującą wektor pracy/przyjemności w określonym przez twórców punkcie. Przykładem aplikacji tej struktury byłoby prześledzenie cyfrowych losów pocisku wystrzelonego przez gracza w analizowanej w dalszej części tego artykułu grze Wolfenstein: The New Order. Obrażenia zadawane za jego pomocą wrogowi (dane) są w czasie rzeczywistym obliczane na podstawie położenia awatara gracza oraz wielu

7 Por. J. Momro Widmontologie nowoczesności. Genezy, Wydawnictwo IBL PAN, Warszawa 2014. 
innych czynników (procesy), co z kolei ma swój efekt w postaci informacji zwrotnej zawartej w interfejsie. Tu kluczowym w świetle postawionych wcześniej pytań badawczych zagadnieniem jest kwestia polityki dostępu i dialektyki widocznego/niewidocznego: to, które informacje są przed graczem ukrywane, a które - wręcz przeciwnie - narzucane, warunkuje z kolei możliwe do podjęcia czynności, których katalog zawiera się w rzutowaniu określonych interakcji na mapę rzeczywistych akcji gracza (np. ruch myszki - obrót kamery - zmiana punktu widzenia). Warstwy autorów i odbiorców zakładają z kolei możliwość negocjacji tak opisanego łańcucha zdarzeń, czy to za pośrednictwem paratekstów (posty pisane na fanowskich forach, wysyłane w grze komunikaty), czy też - ze strony „autorskiej” - modelowania rozgrywki po premierze dzieła za pomocą patchy bądź modyfikacji. W modelu Wardrip-Fruina dwie ostatnie kategorie nie wyczerpują się w prostym podziale nadawczo-odbiorczym, lecz raczej formują przestrzeń potencjalnej realizacji ewokowanych w grze znaczeń.

Przedstawiona wyżej rama interpretacyjna pozwala według mnie na włączenie analizy procesów dystrybucji i monetyzacji do namysłu nad mechaniką i estetyką samych gier. Stosowane przez projektantów rozwiązania, takie jak sprzęgnięcie implementowanego za pomocą platform dystrybucji cyfrowej (jak Steam) systemu osiąnięć (achievements) z wewnętrznym podziałem narracji gry (np. z uwzględnieniem punktów kulminacyjnych fabuły), nie powinny być bowiem rozumiane w oderwaniu od konkretnych praktyk odbioru i fokalizacji. Podobnym przykładem jest ewolucja definicji dodatku do gry, który w ostatnich latach uległ znaczącym przeobrażeniom, zmieniając swoją charakterystykę z prawie pełnoprawnego produktu na zbiór niepowiązanych ze sobą treści o walorach czysto estetycznych.

\section{Fokalizacja i logika operacyjna w praktyce: Wolfenstein: The New Order}

Analiza medialnej hybrydy, jaką są współcześnie wysokobudżetowe produkcje growe, wymaga prześledzenia zmieniających się pozycji samego gracza i jego działań podczas gry. „Do relacji między przedstawianymi elementami i widzeniem, za pomocą którego się je przedstawia, nawiążę, posługując się terminem fokalizacji" - pisze Mieke Bal' ${ }^{8}$. Uzasadniając konieczność rozwinięcia teorii fokalizacji, badaczka wskazuje, że „[inne typologie] nie wprowadzają rozróżnienia między widzeniem, za pomocą którego dane elementy

8 M. Bal Narratologia. Wprowadzenie do teorii narracji, Wydawnictwo UJ, Kraków 2012, s. 147. 
zostają przedstawione, a głosem, który to widzenie werbalizuje"9. W niniejszym artykule argumentuję, że ów „głos" może być nie tylko głosem cyfrowego narratora, lecz także "głosem" fanowskich paratekstów gry bądź „głosem” cyfrowych bibliotek-platform dystrybucji, które poprzez perswazyjne cechy architektury swojego interfejsu bezpośrednio kształtują dyskurs graczy w odniesieniu do danego tytułu.

Użycie fokalizacji jako narzędzia interpretacji w grach wideo pozwala, po pierwsze, na udostępnienie graczom modeli poznawania rzeczywistości, które nie są bezpośrednio związane z ich postacią-awatarem ${ }^{10}$, po drugie zaś, zwraca uwagę na niedostępne (niewidoczne) w inny sposób elementy świata przedstawionego gry (np. poprzez nadanie cyfrowej „kamerze” statusu samodzielnego, interaktywnego „operatora"11). O ile pierwsza funkcja fokalizacji najczęściej sprowadza się do oglądu tej samej sytuacji fabularnej z perspektywy innego bohatera, mnożąc możliwe punkty narracyjnego zaczepienia, o tyle druga o wiele silniej wprowadza osobny, niezależny podmiot, który kieruje wzrokiem gracza i pełni funkcję perswazyjną ${ }^{12}$.

Na tak rozumianej fokalizacyjnej dialektyce odkrywania, zakrywania i kierowania uwagą oraz poczynaniami gracza opiera się gra Wolfenstein: The New Order (dalej jako W:NO), którą wybrałem jako przykład do zaprezentowania potencjału proponowanego w tym tekście podejścia analityczno-interpretacyjnego. Nowy Porządek to dziewiąta odsłona z serii tytułów skupionych wokół postaci Williama B.J. Blazkowicza, amerykańskiego komandosa polskiego pochodzenia, który w alternatywnych realiach II wojny światowej stawia czynny opór nazistowskiej machinie wojennej. W:NO nie odbiega od narzuconej przez poprzednie tytuły konwencji i w dużej mierze wspiera się na fabularnym stelażu pożyczonym z greckiej tragedii, osadzonej tym razem w świecie, w którym stroną przegraną w największym konflikcie zbrojnym XX wieku okazali się alianci. Zgodnie z regułami gatunku FPS w czasie rozgrywki gracz

9 Tamże, s. 147.

Zob. F. Allison Whose Mind is the Signal? Focalization in Video Game Narratives, Proceedings of DiGRA 2015: Diversity of play: Games - Cultures - Identities, s. 1. Zob. M. Nitsche Focalization in $3 D$ Video Games, http://dm.Icc.gatech.edu/ nitsche/download/ Nitsche_Focalization_05.pdf pewne wspólne elementy z perswazyjną retoryką proceduralną lana Bogosta, choć jego wpływowa koncepcja gier jako tekstów kultury, które poprzez swoją mechanikę i strukturę realizują strategie retoryczne, nie jest tu przywoływana w sposób bezpośredni jako zbyt ogólna. 
używa przede wszystkim wszelkiego rodzaju broni palnej ${ }^{13}$, by nazistowską hybris ukarać za przerost techne: mechanika starć z szeregowymi żołnierzami nazistowskiego aparatu opresji (w kolejnych rozdziałach odwiedzamy zarówno podbite polskie ziemie, jak i okupowany Londyn) raczej nie sprzyja narracyjnej refleksji. Kluczowe momenty podzielonej na rozdziały historii są już jednak - odwołując się do omawianego wcześniej modelu Wardrip-Fruina kontrapunktowane przez bardziej skomplikowane procesy analizy i przetwarzania danych warunkujących naszą sprawczość w świecie przedstawionym gry. Innymi słowy, zarówno czas spędzony między misjami w podziemnej bazie ruchu oporu, jak i kulminacyjne starcia z głównymi przeciwnikami pod koniec poszczególnych misji w bardzo perswazyjny sposób tematyzują pakt nadawczo-odbiorczy, którego realizacji moglibyśmy spodziewać się po wysokobudżetowym tytule gatunku First Person Shooter.

Jedną z historycznie wypracowanych konwencji gatunku FPS jest - rozumiana oczywiście w granicach pewnego dyskursu - pełna władza nad awatarem. Zautomatyzowana motoryka działa zazwyczaj niezawodnie, przetwarzając polecenia wprowadzane z urządzeń wejścia (jak naciśnięcie spacji na klawiaturze) na ściśle określone akcje widoczne z poziomu interfejsu graficznego (np. skok postaci). Najbardziej efektywnym sposobem na sprostanie zręcznościowym wyzwaniom stawianym przez FPS-y jest internalizacja zasad mechaniki i aktywne wykorzystywanie wiedzy o poruszaniu się w trójwymiarowym środowisku. Z uwagi na to, że gry wideo są programami funkcjonującymi na zasadzie sprawdzania poprawności ciąów informacji, czynności związane z aktywną grą zawsze wymagają określonego nakładu pracy, która jest tym bardziej skuteczna, im lepiej imituje zaprogramowany scenariusz interakcji. Pokusa pozbycia się technicznych trudności w sterowaniu interfejsem poprzez automatyzację tak rozumianego procesu interakcji z rzadka jednak motywowana jest chęcią szybszego dostępu do zawartości fabularnej; skrypty imitujące „pożądane” zachowanie graczy częściej projektowane (i implementowane) są z myślą o bezproblemowym osiągnięciu w grze wymiernych korzyści wyrażanych akumulacją możliwych do zebrania w jej obrębie cyfrowych dóbr ${ }^{14}$.

13 Jak pouczają nas badacze historii gatunku, "First Person Shootery charakteryzuje pierwszoosobowy punkt widzenia oraz duży nacisk na walkę, zazwyczaj prowadzoną za pomocą broni palnej". Zob. M. Hitchens A Survey of First-person Shooters and their Avatars, "Game Studies" December 2011 Vol. 11, issue 3.

14 S. de Paoli Automatic-Play and Player Deskilling in MMORPGs, "Game Studies" September 2013 Vol. 13 , issue 1. 
W W:NO najbardziej znaczące wydają się właśnie momenty zawieszenia sprawczości gracza i wytrącania go z pozycji przypisanej mu władzy nad cielesnością Blazkowicza. Precyzyjny człowiek-maszyna, hybryda fabularnego bohatera i cyfrowej reprezentacji woli gracza, wymyka się niekiedy bezlitosnemu reżimowi komputacji, prezentując swoje nieprzewidywalne oblicze: nie udaje mu się w porę chwycić poręczy, odwraca wzrok nie w tę stronę, której sobie życzymy, a w ósmym rozdziale, po wyswobodzeniu z więzów, bez zachęty ze strony gracza rozciera ręce i pokazuje nam swój obozowy numer. Zabieg nagłego pozbawienia gracza wpływu na wydarzenia bywał już oczywiście wykorzystywany w grach FPS, lecz motywowały go cele bezpośrednio związane z konkretnym efektem fabularnym, jak było chociażby w F.E.A.R.: First Encounter Assault Recon. W tym kontekście chwilowe „spontaniczne reakcje" Blazkowicza jawią się raczej jako krótka, lecz znacząca przerwa w ciągu wizualnej komunikacji, ekwiwalent Barthes'owskiego punctum, który zmusza nas do określenia się wobec danej sytuacji czy historii.

Przerywniki filmowe, po raz pierwszy w całej serii, oddają głos głównemu bohaterowi. B.J. Blazkowicz opowiada jednak kolejne odcinki swojej historii nie z perspektywy pozytywnie zakończonych przez gracza misji, lecz kroniki pewnej porażki, która polega przede wszystkim na niemożliwości cofnięcia skutków inicjalnej, fabularnej katastrofy. Nieudany szturm w prologu gry, którego rezultatem jest przegrana wojna, pełni też funkcję fabularnej kody pierwszy i ostatni rozdział rozgrywają się w tym samym miejscu kilkanaście lat później.Z perspektywy gracza W:NO to historia sukcesu: udane wykonywanie poleceń ruchu oporu, uwalnianie więźniów, przechwytywanie broni niezbędnej do dalszego prowadzenia walki. Jednak aktanta, dzięki którego poczynaniom możliwy jest postęp fabuły, cechuje niemożliwe do prostego zniwelowania rozdwojenie na fabularną postać Blazkowicza i gracza faktycznie sterującego poczynaniami jego awatara. Ten stary problem poznawczy studiów nad grami oraz powiązane z nim pytanie, „kto kim tak naprawdę gra", jest jednak w W:NO komplikowany przez dodane do samej gry parateksty, takie jak zakładka „kolekcja”, w której zapisywane są m.in. odnalezione przez gracza dokumenty (listy, dzienniki audio) i karty postaci. Przeglądając zawartość kart kolekcji, gracz może poszerzyć swoją wiedzę o obrazie świata przedstawionego - np. dowiedzieć się, że dziadek (Polak) jednej z głównych bohaterek ,,jest niezwykle religijny”, co jest właściwie niemożliwe do wnioskowania na bazie samej rozgrywki. Tego typu dookreślenia dotyczą również prowadzonego przez gracza awatara głównego protagonisty. Karta zatytułowana „B.J. Blazkowicz 196o”, stosując fokalizatora zewnętrznego, objaśnia 
jego motywacje: „W centrum Berlina ukrywa się mała grupa wojowników ruchu oporu [...]. B.J. dołącza do grupy, licząc, że dzięki pomocy zdoła uwolnić świat spod hitlerowskich rządów". Co istotne, paratekstualne interpretacje nie są w pełni zgodne $\mathrm{z}$ interpretacjami, które podaje graczowi sam Blazkowicz w trakcie przerywników filmowych, w czasie których zdarza mu się zwierzać ze swoich wątpliwości co do możliwości ostatecznego zwycięstwa ruchu oporu bądź nawet kwestionować formalną przynależność do tej grupy.

Na przykładzie serii Wolfenstein dobrze widać historyczny rozwój konwencji gatunkowych i strategii negocjowania obecności gracza w świecie przedstawionym gry. Wolfenstein $3 D$ (1992) uznawany jest za przełom w komercyjnej recepcji gier, podobnie jak o rok późniejszy Doom tego samego studia, przy czym oba te tytuły doczekały się w ostatnich latach dobrze przyjętych kontynuacji. Doom z roku 2016 jest jednak koncepcyjnie zdecydowanie inną pozycją niż Wolfenstein: The New Order oraz powiązany z nim samodzielny dodatek The Old Blood.

\section{Praca pamięci, praca ideologii}

W Wolfenstein: The New Order retrofuturystyczne nazistowskie materiały propagandowe, takie jak plakaty namawiające do wypicia kawy w bazie wojskowej na Księżycu, odgrywają głównie humorystyczną rolę narracyjnej ramy odniesienia ${ }^{15} \mathrm{dla}$ graczy. O ile rozpoznawanie nawiązań do współczesnej popkultury jest dla gracza tylko kolejną zabawą, o tyle dla fabularnego bohatera, B.J. Blazkowicza, stanowi dystopijną pracę scalania rozbitych elementów narracji w koherentny scenariusz rzeczywistości. Problemy z (auto)identyfikacją są transponowane skokowo, z gracza na awatara bohatera, również z powodu (uzasadnionego w diegezie) urazu głowy i częściowej amnezji protagonisty. Niektórzy badacze gier FPS dostrzegają w tym gatunku zjawisko stopniowego zastępowania narracji przestrzennej i kinetycznej przez nieliniową narrację emergentną ${ }^{16}$, czemu jednak przeczyłaby rosnąca popularność praktyk speedrunu oraz komercyjny sukces udanego odświeżenia serii Doom (2016).

Czy w świetle powyższych uwag można zidentyfikować moment połączenia dyskursów pracy i zabawy, strategii dystrybucji i praktyk odbioru? Odpowiedzi można szukać w aplikacjach i serwisach, które z nadrzędnego

15 Zob. M. Bal Narratologia..., s. 122.

16 Zob. R. Klevjer La via della pistola. L'estetica dei first person shooter in single player, w: Doom. Giocare in prima persona, red. M. Bittanti, S. Morris, Costa \& Nolan, Milano 2006. 
poziomu zarządzają całą współczesną strukturą komputerowej rozrywki, z platformą Steam jako praktycznym monopolistą. We współczesnych tytułach segmentu wysokobudżetowego funkcjonowanie dyskursów związanych z pracą i zabawą przypomina pracę ideologii według klasycznego rozumienia Luisa Althussera" - jako wysiłek przekształcania jednostek w podmioty. Funkcją ideologii w takim ujęciu jest zbudowanie przekonania o naturalności zastanego stanu rzeczy. W konsekwencji w przypadku gier AAA praca ideologii jest zawsze dwojaka: zaakceptowanie konwencji przedstawienia świata w grze dotyczy samych graczy (którzy powinni zinternalizować zarówno mechanikę, jak i fabułę, by czerpać długotrwałą przyjemność z rozgrywki), a także bohaterów - choć ich niezgoda na zastaną rzeczywistość jest jednym z najczęściej wykorzystywanych w grach schematów zawiązania akcji, to są oni z konieczności „uwięzieni” w logice cyfrowego świata, w którym się poruszają. Zaangażowanie w rozgrywkę z punktu widzenia graczy nie musi przy tym być powiązane z immersją czy kategorią realizmu. Tak jak nie trzeba wierzyć w magię, by zatracić się w świecie powieści Tolkiena, tak nie trzeba uwierzyć w nazistowskie państwo, kontrolujące w latach 6o. XX wieku większą część globu, by czerpać przyjemność z uczestniczenia w alternatywnej historii Wolfensteina. Musi tu jednak zachodzić pewna ciągłość: podstawowe warstwy gry (dane i procesy) nie mogą wchodzić ze sobą w otwarty konflikt. Jeśli zaś już niewspółmierność taka zachodzi, jej znaczenie jest dodatkowo podkreślane przez konstrukcję fabuły i odpowiednio wygrywane znaczeniowo jako nietypowy i natychmiast zwracający uwagę odbiorcy konflikt. Tego typu eksperymenty są jednak jak na razie zarezerwowane raczej dla tytułów indie (wymownymi przykładami będą tu The Stanley Parable, The Magic Circle czy The Beginner's Guide), choć tego typu tropy interpretacyjne zdarza się ewokować wysokobudżetowym grom japońskim, np. przez związanie ze sobą dwóch zależnych od siebie awatarów (przypadek The Last Guardian Fumito Uedy). Udana praca ideologii w ujęciu Althussera sprawia, że dopracowane pod względem graficznym i fabularnym tytuły nie muszą ukrywać nawet rażących elips logicznych i historycznych niekonsekwencji. Skoro widzimy na własne oczy, że ubrany jak Lawrence z Arabii i mówiący we współczesnym języku tureckim żołnierz z powodzeniem szarżuje konno na gniazda karabinów maszynowych w Battlefield I, a pruscy junkrzy na jego widok pierzchną w popłochu, to znaczy, że nasza optyka już została zmieniona, ponieważ

17 Zob. L. Althusser W imię Marksa, przeł. M. Herer, Wydawnictwo Krytyki Politycznej, Warszawa 2009. 
rozpoznaliśmy odpowiednie tropy wizualne i audialne i właśnie dokonaliśmy ich rekonfiguracji, aktywnie uczestnicząc w medialnym spektaklu rozgrywającym się na ekranie monitora.

Innymi słowy, fokalizacja w wysokobudżetowych grach wideo dążyłaby do wewnętrznej zgody. I choć techniczne detale mogą się w przypadku poszczególnych tytułów między sobą różnić, dochodzi tu do pewnego rodzaju trójstronnego paktu: fabularna postać (np. B.J. Blazkowicz) musi w pewnym sensie zobaczyć w świecie gry samą siebie i w siebie też uwierzyć, wtedy zaś gracz ma motywację do podjęcia pewnej mechanicznej pracy z interfejsem i mechaniką, które stawiając umiarkowany opór, pozwalają na osiągnięcie ostatecznej fabularnej satysfakcji: ukończenie gry.

Jedną z tez stawianych we wstępie artykułu jest ewolucja w kierunku dyskursywnego przedstawiania gier jako pola pewnego koniecznego do podjęcia wysiłku. Jeśli nawet wysokobudżetowy tytuł wprost odwołuje się do pojęć spontanicznej zabawy czy niewymagającej zbytniego namysłu rozrywki ${ }^{\mathbf{1 8}}$ (por. przypadek Diablo III Blizzarda), z reguły zawiera w sobie mechanizmy nagradzające zainwestowany weń czas. Jednym ze sposobów jest umożliwienie graczom zdobycia konkretnych osiągnięć, sygnalizowanych pojawieniem się odpowiedniej ikony konotującej sprostanie danemu wyzwaniu. Ich rola w społecznościowym wymiarze gry różni się w zależności od platformy (konsole poszczególnych firm, komputery), jako przykładu ich działania warto więc użyć najpopularniejszej cyfrowej platformy dystrybucji, pełniącej jednocześnie funkcje platformy społecznościowej - serwisu Steam firmy Valve. Osiągnięcia na Steamie są z punktu widzenia twórców opcjonalnym dodatkiem do strony związanej z daną grą. Są widoczne zarówno z poziomu sklepu,jak i już po zakupie produktu - jako graficznie wyróżniony fragment prywatnej biblioteki gier użytkownika. Można zauważyć, że poszczególne produkcje różnią się od siebie nie tylko ich ilością, ale i typem: wysokobudżetowe tytuły z reguły mają ich dużo, co najłatwiej wytłumaczyć marketingowym chwytem sugerującym potencjalnym klientom długą rozgrywkę i liczne wyzwania. Wiele z osiągnięć jest powiązanych z kluczowymi

18 Interesującym przykładem ścierania się różnych dyskursów dotyczących zabawy i przyjemności w grze jest przypadek cyklu "Play Your Way Thursday", w którym przesyłane przez fanów strategie rozwoju postaci są przez zarządzających społecznością pracowników Blizzarda (tzw. community managerów) selekcjonowane i przedstawiane na oficjalnej stronie gry Diablo III. Kontrowersje dotyczące przekładalności efektywności oraz skuteczności danej strategii na rzeczywistą przyjemność czerpaną z gry są stałym elementem dyskusji w komentarzach tej rubryki. Zob. http://tinyurl.com/jzyooze. 
fragmentami narracji. W grze The Elder Scrolls: Skyrim na 75 możliwych do zdobycia ponad 20 odwołuje się do podjęcia określonego wyboru fabularnego, niekiedy tożsamego z wypełnieniem zadania niezbędnego do dalszego postępu opowiadanej w grze historii. Osiągnięcia są więc pewnego rodzaju podpowiedzią, jak pozycjonować siebie w grze - stanowią też wskazówkę co do zawartości gry, zbliżoną do książkowego spisu treści. Mogą aktywować również wymiar kompetytywny: nasi „znajomi” na Steamie bez trudu sprawdzą nasze postępy, po prostu zaglądając do odpowiedniej zakładki w profilu. Chociażby z tego tylko powodu trudno już postrzegać gry komputerowe jako indywidualną przygodę i cyfrową samotnię, w której liczą się spersonalizowane narracje i budowane na bieżąco historie. Dziś jest raczej odwrotnie: już na etapie projektowym twórcy tak profilują węzłowe punkty fabuły, by dobrze wpisywać je w zbiorowy odbiór dzieła, mierzalny za pomocą późniejszej analizy statystyk odpowiednich osiągnięć. Warstwy autorów i twórców pozostają nierozłączne, choć widać dysproporcję w ich sprawczości - nawet gracz stroniący od udziału w fanowskich paratekstach już przez sam fakt grania w ramach danej platformy dostarcza jej właścicielom informacji, które są później wykorzystywane przy projektowaniu kolejnych tytułów.

\section{V.Stwarzanie, projektowanie, przywoływanie}

Jednym z najciekawszych i najbardziej znaczących elementów rozbudowanych narracyjnie gier $\mathrm{AAA}^{19}$ jest moment, w którym mechaniczna (i możliwa do zautomatyzowania) praca gracza spotyka się z pracą pamięci, którą należy dopiero wykreować. W przypadku gier cRPG jest to czas tworzenia nowej postaci, kiedy to wybiera się cechy, wygląd oraz umiejętności głównego bohatera. Gry FPS często rozciągają moment tak rozumianego podmiotowego dookreślenia i problematyzują go fabularnie, wprowadzając do tego procesu znaczący udział elementów środowiska i świata przedstawionego. W przypadku gatunkowych form hybrydowych, coraz częściej spotykanych w segmencie AAA, odbywa się to przy dużym udziale narracji wizualnej, jednocześnie pozycjonującej awatara w przestrzeni gry oraz wyznaczającej za pomocą interfejsu granic między tym, co diegetyczne, a tym, co poza diegezą

19 Pomijam tu gry sieciowe, w których fabuła i narracja nie tyle schodzą na dalszy plan, co są nieustannie odtwarzane w cyklach wyznaczanych każdorazowo przez rozpoczęcie i zakończenie rozgrywki. 
gry $^{20}$. Przykładem może być czwarta odsłona Fallouta, postapokaliptyczna gra łącząca w sobie elementy role-playing i klasycznego shootera - bardzo szybko otrzymujemy dostęp do narzędzia, które zdecydowanie zmienia nasz sposób poznawania przestrzeni gry oraz rozwiązywania stawianych nam przez nią wyzwań. Jest to power armor, specjalny pancerz, w poprzednich częściach gry możliwy do wykorzystania dopiero pod koniec ścieżki fabularnej, w Falloucie 4 zaś bardzo potężna maszyna, o którą należy dbać, zdobywając materiały niezbędne do jej rozbudowy i poprawnego działania. Bliższe przyjrzenie się grze Bethesdy pozwala też na obserwację zmieniającej się filozofii projektowej wysokobudżetowych gier, jako że pierwsze dwa tytuły serii miał premierę jeszcze w latach 90. XX wieku. W ostatniej odsłonie Fallouta tradycyjnie powiązana z fabułą eksploracja przestrzeni gry traci nieco na swym narracyjnym znaczeniu i staje się bardziej ekonomiczną koniecznością. Żmudne i powtarzalne zbieranie zasobów, choć logicznie wkomponowane w fabularną ramę świata po atomowej zagładzie, jest w wielu miejscach konieczne do pokonania konkretnych mechanicznych wyzwań (np. silnie opancerzonych przeciwników). Konieczność sprostania tym przeszkodom zastępuje w pewnym sensie klasyczne wyznaczniki fabularne - starcie z wyjątkowo kłopotliwym bossem wymaga od gracza uwzględnienia na poziomie interakcji odpowiednich taktyk z poziomu danych. Gracz pełni tu funkcję służebną wobec mechanizmu: zabawa eksploracji i audiowizualnej lektury podporządkowana jest pracy akumulacji cyfrowego kapitału.

By skutecznie nakłonić gracza do inwestycji czasu i uruchomić ostatnie dwa, przenikające się poziomy modelu Wardrip-Fruina - autorów i odbiorców - wysokobudżetowe produkcje odwołują się również do bardziej bezpośrednich strategii pamięciowej fokalizacji. W The Elder Scrolls: Morrowind otwierająca sekwencja przedstawia gracza z perspektywy kogoś, kto „jako więzień zrodzony pewnego dnia z nieznanych rodziców został wysłany pod strażą, bez słowa wyjaśnienia, do Morrowind, nieświadom roli, jaką odegra w dziejach tej krainy". Minione wydarzenia, choć z pozoru nieważne, muszą jednak zostać odtworzone („przypominanie” równałoby się tu zatem kreacji) - bohater bez przeszłości jest bowiem dla systemu gry niemożliwy do zoperacjonalizowania w kategoriach teraźniejszości. Brak danych wejściowych nie tyle więc utrudnia, co zawiesza w czasie akt fokalizacji. Jak pisze Mieke Bal, 
Szczególnym przypadkiem fokalizacji [...] jest pamięć. Pamięć to akt „widzenia" przeszłości, lecz jako akt jest umiejscowiona w pamięci obecnej. Często jest to akt narracyjny: niepowiązane ze sobą elementy zaczynają się układać w opowieść, która może być potem zapamiętana i w końcu opowiedziana. ${ }^{21}$

Można tu dopowiedzieć, że gry zawsze domagają się jakiegoś fokalizatora zewnętrznego - odbiorcy, który nie tylko we własnym zakresie zasklepi luki fabularne, ale i umieści wydarzenia na ekranie w odpowiedniej ramie narracyjnej. Popularność „odgrywania” postaci i przekazywania później swojej nałożonej na rozgrywkę narracji - np. przez nagrywanie filmów z kategorii „role-playing let's play” - jest praktyką o niesłabnącej mimo postępu technologicznego popularności. U początków drogi do komercyjnego sukcesu gry aktywnie wspierały praktyki odbioru tego typu - dość wspomnieć obszerną, drukowaną historię fikcyjnej krainy Britanni, dołączaną do egzemplarza gry Ultima IV, bez lektury której fabuła tego przełomowego tytułu słynnej serii cRPG pozostawała dla gracza co najmniej trudna do rozszyfrowania.

\section{Zakończenie}

Proponowane tu ujęcie gier z segmentu wysokobudżetowego inkorporuje schemat wypracowany w obrębie studiów nad oprogramowaniem (software studies) i łączy go z klasycznymi narzędziami literaturoznawczej narratologii. Kod gry, który warunkuje podstawowe poziomy danych i procesów w omawianej tu propozycji Wardrip-Fruina, może i powinien być traktowany jako tekst kultury - również dlatego, że współczesny obieg medialny wysokobudżetowych gier związany jest z platformami i narzędziami dystrybucji bezpośrednio zarządzanymi przez algorytmy. Zarówno produkowane przez fanów, jak i występujące w medialnej otoczce gry parateksty problematyzują naszą obecność w cyfrowych światach, a dyskursy pracy i zabawy przenikają się nawzajem wśród ciągle powstających taktyk negocjacji przestrzeni interakcji gier wideo. Komplikowanie procesów postrzegania i mnożenie punktów fokalizacji wynika z coraz mocniejszego zadłużenia gier AAA u narzędzi wspomagających ich cyfrową dystrybucję. Bez konta na platformie Steam nie da się legalnie uruchomić większości współczesnych, wysokobudżetowych pecetowych gier, a w konsekwencji nie da się też uciec od konfrontacji ze

21 M. Bal Narratologia..., s. 152. 
zalgorytmizowaną rzeczywistością, obejmującą zarówno aspekt technologiczny (wprowadzanych na bieżąco do gry poprawek), jak i społecznościowy (widoczna dla wszystkich użytkowników lista zdobytych osiągnięć). Gdy Mia Consalvo pisała o „paratekstualnych przedsiębiorstwach” zaangażowanych w produkcję wiedzy o tym, jak „powinno się” grać w gry ${ }^{22}$, narzędzia komplikujące zależności między technologicznymi i narracyjnymi aspektami gier wideo nie były jeszcze tak rozbudowane - można jednak zaryzykować prognozę, że ich znaczenie będzie już tylko rosnąć.

\section{Abstract}

\section{Mateusz Felczak}

JAGIELLONIAN UNIVERSITY (CRACOW)

Discourses on Work and Play in the Big-Budget Video Games: Focalization and Operational Logic

Felczak's analysis of discourses on work and play in big-budget video games is based on a method that draws on Mieke Bal's concept of focalization (2012) as well as the tools of operational logic developed by Noah Wardrip-Fruin (2012). The article aims to propose a research method that would link narratological research with a critical analysis of strategies used in the development and distribution of digital games. The main argument concerns the shifting definition of computer-based entertainment, from aimless play towards the development (and description) of games in terms of effort, work and reward. To illustrate her thesis, Felczak analyses the game Wolfenstein: The New Order as well as selected titles from the CRPG genre (from the series The Elder Scrolls and Fallout).

\section{Keywords}

work, play, focalisation, operational logic

22 M. Consalvo Cheating. Gaining Advantage in Videogames, The MIT Press, Cambridge 2007, s. 84. 